\section{Wine Grape Cultivar Performance in the Four Corners Region of New Mexico in 2010-12}

\author{
Kevin Lombard ${ }^{1,4}$, Bernd Maier ${ }^{2}$, Franklin J. Thomas ${ }^{1}$, \\ Mick O’Neill ${ }^{1}$, Samuel Allen ${ }^{1}$, and Rob Heyduck ${ }^{3}$
}

AdDitional INDEX wORDs. freeze damage, grapevine, high-elevation viticulture, interspecific Vitis sp. hybrid, V. vinifera

\begin{abstract}
Summary. Commercial wine grape (Vitis sp.) production in northwestern New
Mexico and the greater Four Corners region is now supported by four wineries. The challenges of growing grape vines in northwestern New Mexico include cold winter temperatures and killing spring frosts exacerbated by a semiarid climate and elevations exceeding $1700 \mathrm{~m}$. Nineteen nongrafted European wine grape (Vitis vinifera) and interspecific hybrid wine grape cultivars were planted in 2007 and evaluated between 2010 and 2012. Among European wine grape cultivars, Agria, Malbec, Sangiovese, Viognier, Müller-Thurgau, and Sauvignon Blanc performed poorly or failed altogether. Interspecific hybrid cultivars Baco Noir, Kozma 55, Leon Millot, Chardonel, Seyval Blanc, Siegfried, Traminette, Valvin Muscat, and Vidal Blanc showed greater adaptability to a high-elevation intermountain western U.S. site, yielding on greater than $71 \%$ of their vines in each year (except Kozma 55 which only produced on $38 \%$ of its vines in 2012 due to severe spring frost damage). We speculate that fruit-bearing shoots on these vines arose from latent buds that survived when primary buds were killed from spring frost events. Once vines were established, grape berry sugar and $\mathrm{pH}$ appeared to be within acceptable ranges (3-year mean above $21 \%$ soluble solids and juice $\mathrm{pH}$ of 3.2 ), suggesting regional potential to produce favorable wines within acceptable commercial wine grape production ranges. Selection of sites without considerable frost risk and other mesoclimate variances is critical when considering vineyard establishment at highelevation locations.
\end{abstract}

A renaissance in locally produced, locally branded foods is occurring in the Four Corners

Thanks to Jeremiah Baumgartel, Don Hyder, Richard Heerema, Dawn Vanleeuwen, and other peer reviewers for their helpful critique of this manuscript. We also thank Dave Arnold (Wines of the San Juan, Turley, NM), Henry Street (Ponderosa Valley Vineyards and Winery, Ponderosa, NM), Bart Wilsey, Paulo D'Andrea (Luna Rossa Winery and NM Vineyards, Deming, NM), and Double A. Vineyards (Fredonia, NY) for their support of this project. Thanks to the Navajo Agricultural Products Industry for soil/compost analysis. Thanks to Jerry Dangl and the University of California Plant Foundation Laboratory (Davis, CA) for assistance with the DNA analysis. Thanks to the NMSU-Agricultural Experiment Station (Las Cruces, NM) and San Juan College (Farmington, NM) for salary and funding support. Thanks to Aiessa Wages and Latisha Yazzie for help in the vineyard during summers.

Use of trade names does not imply endorsement of the products named nor criticism of similar ones not named.

${ }^{1}$ Department of Plant and Environmental Sciences, Agriculture Science Center at Farmington, New Mexico State University, P.O. Box 1018, Farmington, NM 87499-1018

${ }^{2}$ Extension Viticulture Specialist, New Mexico State University Cooperative Extension Service Viticulture Specialist, P.O. Box 30003 MSC 3AE, Las Cruces, NM 88003

${ }^{3}$ John T. Harrington Forestry Research Center, New Mexico State University, P.O. Box 359, Mora, NM 87732

${ }^{4}$ Corresponding author. E-mail address: klombard@ nmsu.edu. region, that portion of the southwestern United States where the state boundaries of New Mexico, Arizona, Colorado, and Utah converge. Growers again view fruit crops, including wine grape, as a profitable specialty crop to propel a local agricultural/tourism economy. Current private grape acreage in the entire Four Corners region is $\approx 20$ ha, but is supported by at least four boutique wineries with vineyards, and the number of small test vineyards established in the area is increasing.

Northwestern New Mexico has high-elevation geography and a climate typical of many parts of the intermountain western United States, the region is bounded by several mountain ranges with peaks greater than $2900 \mathrm{~m}$ and is of varied topography from mountain foothills, expansive mesas, to narrow fertile river valleys. The La Plata, Animas, and San Juan rivers provide irrigation water to small-scale valley-bottom farms in these respective valleys. Navajo Lake $\left(63.1 \mathrm{~km}^{2}\right.$ and fed by the upper San Juan River) provides irrigation water to the greater than 80,000 acre Navajo Agricultural Products Industry farm, a Navajo Nation commercial farm entity located on a mesa top south of Farmington, NM. Regional climate is high desert, semiarid (due to nearby mountainous rain shadow effect) with a mean annual precipitation of 8.16 inches $(207.264 \mathrm{~mm})$ (Smeal, 2006). Daily diurnal temperature variation is extreme, easily swinging $20^{\circ} \mathrm{C}$.

Cultivar evaluation research is an important step in determining commercial viability of grape cultivars in various mesoclimates of potential production regions. In the intermountain western United States, viticultural performance has been evaluated primarily at low-elevation sites such as Prosser, WA, elevation $270 \mathrm{~m}$ (Davenport et al., 2008; Keller et al., 2005; Mills et al., 2006); Summerland, BC, Canada (interior), elevation $454 \mathrm{~m}$ (Reynolds et al., 2004); and Parma, ID, elevation $750 \mathrm{~m}$ (Fallahi et al., 2005; Shellie, 2007). High-elevation trials have been reported for Reno, NV, elevation $1373 \mathrm{~m}$ (Evans et al., 2005) and Grand Junction, CO, elevation $1414 \mathrm{~m}$ (Caspari and Montano, 2012; Hamman, 1993; Hamman et al., 1998). Northwestern New Mexico geography and climate closely resembles Grand Junction, CO's, and northwestern New Mexico growers

\begin{tabular}{llll}
\hline $\begin{array}{l}\text { Units } \\
\text { To convert U.S. to SI, } \\
\text { multiply by }\end{array}$ & U.S. unit & SI unit & $\begin{array}{l}\text { To convert SI to U.S., } \\
\text { multiply by }\end{array}$ \\
\hline 0.4047 & acre $(\mathrm{s})$ & $\mathrm{ha}$ & 2.4711 \\
29.5735 & $\mathrm{fl} \mathrm{oz}$ & $\mathrm{mL}$ & 0.0338 \\
0.3048 & $\mathrm{ft}$ & $\mathrm{m}$ & 3.2808 \\
2.54 & inch $(\mathrm{es})$ & $\mathrm{cm}$ & 0.3937 \\
25.4 & inch $(\mathrm{es})$ & $\mathrm{mm}$ & 0.0394 \\
0.4536 & $\mathrm{lb}$ & $\mathrm{kg}$ & 2.2046 \\
1.1209 & $\mathrm{lb} / \mathrm{acre}$ & $\mathrm{kg} \cdot \mathrm{ha}^{-1}$ & 0.8922 \\
2.5900 & $\mathrm{mile}{ }^{2}$ & $\mathrm{~km}$ & 0.3861 \\
1 & $\mathrm{ppm}$ & $\mathrm{mg} \cdot \mathrm{kg}^{-1}$ & 1 \\
$\left({ }^{\circ} \mathrm{F}-32\right) \div 1.8$ & ${ }^{\circ} \mathrm{F}$ & ${ }^{\circ} \mathrm{C}$ & $\left({ }^{\circ} \mathrm{C} \times 1.8\right)+32$
\end{tabular}


often reference viticultural work conducted there. As a whole, these studies from low- and high-elevation sites share some similarities with northwestern New Mexico and offer some cultivar performance information for semiarid conditions.

Like Grand Junction, northwestern New Mexico has high solar irradiation, which amplifies minimummaximum temperatures (Hamman et al., 1998). However, northwestern New Mexico is $\approx 300 \mathrm{~m}$ higher in elevation than Grand Junction. A mean temperature decline (temperature lapse rate) of $0.65{ }^{\circ} \mathrm{C}$ for every $100 \mathrm{~m}$ increase in elevation (Wallace and Hobbs, 2006) can be assumed and temperature lapse rates vary across high-elevation, complex terrain, leeward and windward slopes, and valley floors (Minder et al., 2010; Rolland, 2002). Given these site-specific factors, cultivar performance comparisons between sites begin to diverge.

Forgotten in sparsely circulated research reports is the Grape and Wine Production in the Four Corners Region formative work, conducted in the late 1960s and 1970s by Dutt et al. (1981) and Mielke et al. (1980) with cooperators from the New Mexico State University (NMSU) Agricultural Science Center at Farmington (ASC-Farmington). Their work was partially connected to Grand Junction's early wine grape trials (Mielke et al., 1980). In 1968, the ASCFarmington trialed 165 wine grape (V. vinifera), fox grape [Vitis labrusca (e.g., 'Concord')], muscadine (Vitis rotundifolia), and North American and French-American interspecific hybrid grape cultivars (A.E. Stewart, E.J. Gregory, and J.G. Karas, unpublished data). Blowing sand, which removed buds on young vines, zinc deficiency due to a calcareous layer in the root zone, and winterkill contributed to the demise of poorperforming cultivars (A.E. Stewart, E.J. Gregory, and J.M. Jordon, unpublished data). Poor adaptability of European wine grape cultivars compared with interspecific hybrid cultivars like Baco and Seibel 5898 was especially noted (A.E. Stewart, E.J. Gregory, and J.M. Jordon, unpublished data; J.M. Jordan and M.A. Rosales, unpublished data).

Although there has been previous grape cultivar trial work conducted at the ASC-Farmington, cultivars tested were in replicated and unreplicated plots. Moreover, no commercial wineries existed in the area when earlier research was conducted, nor was information made widely available as peer-reviewed work. Historical minimum and maximum temperature means recorded at the ASC-Farmington range from 19 to $4 \mathrm{l}^{\circ} \mathrm{F}\left(-7.2\right.$ to $\left.5.0{ }^{\circ} \mathrm{C}\right)$ in January to 60 to $91{ }^{\circ} \mathrm{F}$ (15.8 to $32.8^{\circ} \mathrm{C}$ ) in July (Smeal et al., 2006), suggesting a suitable climate for wine grape production. Considering large informational gaps and renewed interest in grapes, growers are requesting up-to-date information on cultivar adaptability to northwestern New Mexico's mesoclimates. This report describes grapevine production performance of 19 nongrafted red and white wine grape cultivars.

\section{Materials and methods}

The ASC-Farmington experimental vineyard is located at an elevation of $1720 \mathrm{~m}$ (lat. $36^{\circ} 41^{\prime} 20.95^{\prime \prime} \mathrm{N}$, long. $\left.108^{\circ} 18^{\prime} 45.56^{\prime \prime} \mathrm{W}\right)$. Soil is classified as a Doak sandy loam (fine-loamy, mixed, mesic Typic Haplargid), having a $\mathrm{pH}$ above 8 and containing less than $1 \%$ organic matter (Keetch, 1980).

A total of ten red and nine white wine European wine grape, interspecific hybrids, and North American grape cultivars (Table 1) were obtained in Spring 2007 in the form of prerooted cuttings or were propagated at the San Juan College greenhouse (Farmington, NM) from vines located in trials at the NMSU ASCs at Los Lunas and Alcalde, NM. One of the red hybrid cultivars supplied was labeled simply as Kozma without reference to a particular clone. DNA analysis later conducted in June 2013 by University of California Plant Foundation Laboratory (Davis, CA) established that the sample had non- $V$. vinifera alleles at two of the eight loci tested, indicating a backcross to $V$. vinifera, perhaps several generations back (J. Dangl, personal communication). Further testing confirmed that the sample matched 'Kozma csvt 55', accession number DVIT 3315, at the National Clonal Germplasm Repository (Davis, $\mathrm{CA}$ ) and that the DNA profile also showed 'Pearl of Csaba' could be a parent, consistent with the published pedigree of 'Kozma csvt 55' (Vitis International Variety Catalogue,
2007; J. Dangl, personal communication). Rootstocks were not used in this trial because of the extreme risk of winterkill below the graft union at our high-elevation site.

Vines were planted 3 July 2007 on 4 - $\mathrm{ft}$ spacing between vines and $12 \mathrm{ft}$ between rows in a north-south orientation, totaling $\approx 1$ acre. Vines were trained to the cordon wire between 2007 and 2009 growing seasons as single trunks using a two-wire vertical trellis (simple curtain) system. This was accomplished by training a single cane to the cordon wire located $5 \mathrm{ft}$ aboveground, bending and tying it along the fruiting wire $4 \mathrm{ft}$ in length and allowing shoots to droop over a foliage support wire located 12 inches above the cordon wire. Drip lines with $1.5 \mathrm{~L} \cdot \mathrm{h}^{-1}$ emitters spaced every $2 \mathrm{ft}$ provided irrigation to vines, primarily between flowering and veraison, and postharvest. In 2011,15 inches total water was applied and in 2012, that amount increased to 20 inches. Vines were top dressed with compost $\left(450 \mathrm{mg} \cdot \mathrm{kg}^{-1}\right.$ nitrate) in May 2010. Vines received $20 \mathrm{lb} /$ acre nitrogen in the form of urea ammonium nitrate [UAN $(32 \mathrm{~N}-$ $0 \mathrm{P}-0 \mathrm{~K})$ ] in 2012.

Vines were hand pruned each year during dormancy between late March and early April. Western bindweed (Convulvulus arvensis) control was attained through periodic spot spraying with glyphosate in 2008 . Weed control thereafter was attained by hand cultivation bimonthly between vines and by rototilling between rows monthly during the growing season. Beginning in 2012, weed control between vines was done bimonthly using a tractormounted under vine weeder (Clemens Radius; Clemens Technologies, Wittlich, Germany).

Temperature monitoring. A National Weather Service maximum and minimum thermometer (Nimbus PL; Sensor Instruments, Concord, $\mathrm{NH}$ ) housed in a regulation, louvered instrument shelter and located $\approx 20 \mathrm{~m}$ from the vineyard was used to calculate growing degree days (GDD). Additional on-site weather data were obtained from the New Mexico Climate Center (NMCC, 2013) weather station located $375 \mathrm{~m}$ from the vineyard and consisting of air temperature, relative humidity, solar radiation, wind speed, wind direction, and rain-depth 
Table 1. Cultivar, ancestry and origin of 19 red and white European and interspecific hybrid wine grape cultivars evaluated 2010-12 at the New Mexico State University Agricultural Science Center at Farmington, NM [elevation $1720 \mathrm{~m}(5643.0 \mathrm{ft})$ ]. Note: Ancestry referencing Vitis International Variety Catalogue (2007) unless otherwise noted. European cultivar refers to Vitis vinifera.

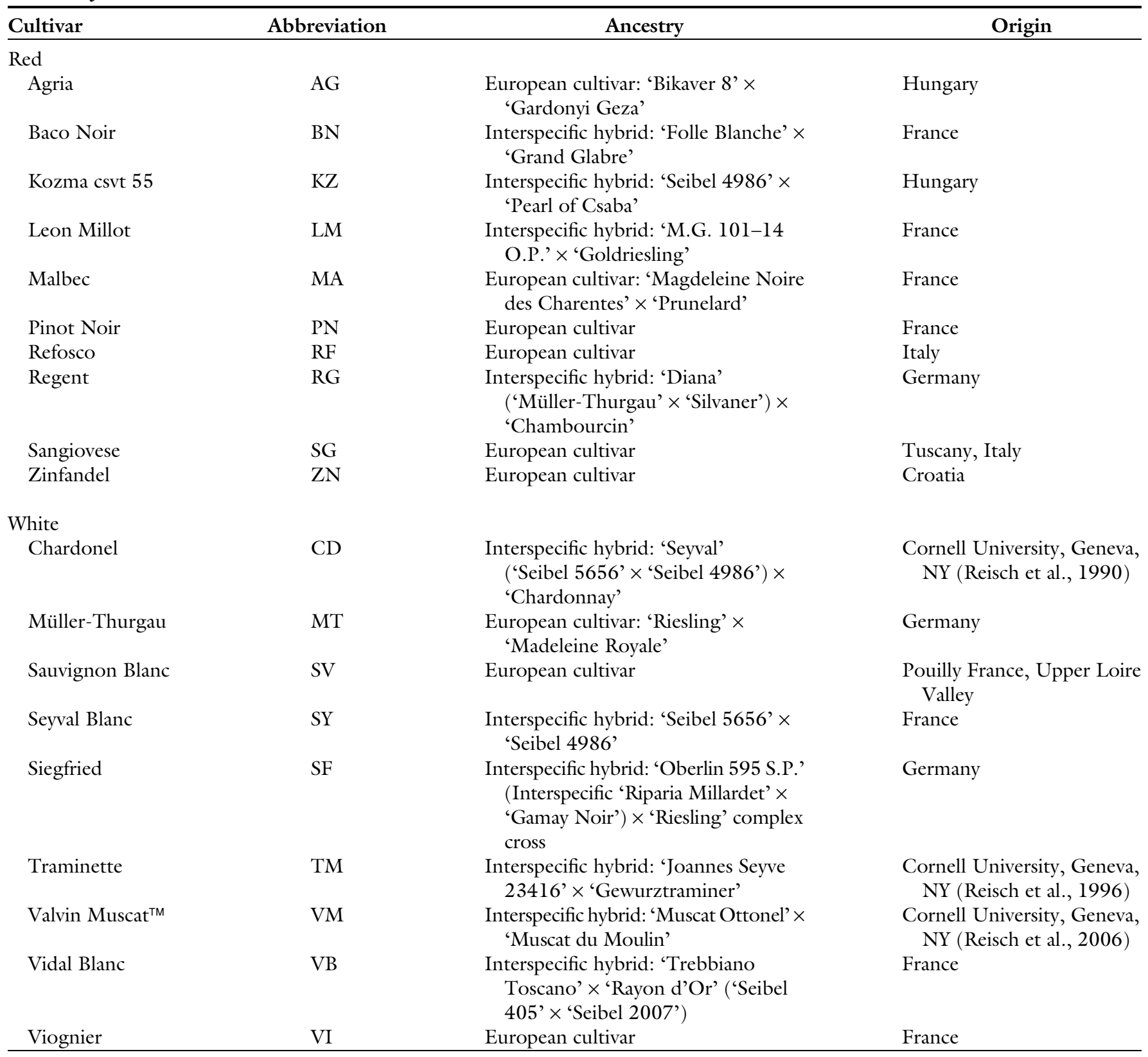

sensors wired to a datalogger (CRl0; Campbell Scientific, Logan, UT). A temperature-only datalogger (Watchdog model 400; Spectrum Technologies, Plainfield, IL) was mounted within the experimental vineyard at the cordon wire $5 \mathrm{ft}$ aboveground level and used to corroborate official weather station data.

Growing degree days were calculated using a simple daily average with a base of $10{ }^{\circ} \mathrm{C}$ and no upper limit (Winkler et al., 1974) with the following formula (McMaster, 1997):

$$
\begin{gathered}
\frac{T_{\mathrm{MAX}}+T_{\mathrm{MIN}}}{2}-T_{\mathrm{BASE}} \\
\text { if } \frac{T_{\mathrm{MAX}}+T_{\mathrm{MIN}}}{2}<T_{\mathrm{BASE}} \\
\text { then } \frac{T_{\mathrm{MAX}}+T_{\mathrm{MIN}}}{2}=T_{\mathrm{BASE}}
\end{gathered}
$$

where $T_{\mathrm{MAX}}$ is the maximum daily temperature, $T_{\mathrm{MIN}}$ is the minimum daily temperature, and $T_{\mathrm{BASE}}$ is the temperature base of $10{ }^{\circ} \mathrm{C}$. The GDD calculated for each day were summed to obtain monthly and annual totals.

VINE GROWTH ANALYsis. Grape phenology was evaluated using the modified E-L (Eichhorn and Lorenz) system (Coombe, 1995), which covers 47 grape growth stages from dormancy, budbreak, bloom, veraison, and harvest to leaf senescence. Excluding harvest date, modified E-L measurements were performed on 16 sampling dates between 9 Apr. and 17 Aug. 2010, nine sampling points between 18 Apr. and 17 Aug. 2011, 
and 16 sampling points between 29 Mar. and 30 Aug. 2012. Budbreak was defined as an E-L 4, when green tips of the first leaf tissue were visible (Coombe, 1995), and was recorded as days of year (DOY) elapsed since the start of the current year.

We evaluated E-L stage directly before and after forecasted spring frost events. Spring frosts occurred on two occasions in 2010 (30 Apr. to 2 May and 12 May), 16 Apr. 2011, and 27 May 2012. On the following day's assessment, frost-damaged vines greater than E-L 4 stage exhibited brown leaves and wilted shoots. Vines were then scored for frost damage using a simple measure, where $0=$ no foliar damage and $\mathrm{l}$ = foliar damage observed. Vine damage per entry was then expressed as a percentage of the total number of vines planted. The probability of spring frost events occurring at the ASC-Farmington site was also calculated using the frost risk (Frisk) model (Snyder and de MeloAbreu, 2006) and (from) 44-year historical weather data from NMSU-ASC.

HARvest. Before harvest, $\approx 10$ 20 berries were randomly pulled from several vines of a given entry about every other day and pressed in the field with a handheld garlic press to yield $\approx 2 \mathrm{~mL}$ of juice for sugar analysis. Seed color and astringency were also examined. Target harvest criteria were berries having $>21 \%$ soluble solids, using a handheld digital refractometer (PAL-1; ATAGO, Tokyo, Japan), and dark brown, nonastringent tasting seeds. When these criteria were met, all vines for a particular entry with marketable grapes were counted (to calculate percentage vines harvested) and harvested (up to $n=24$ vines per entry). Day of harvest was recorded as elapsed number of days from budbreak. Yield was measured by counting and then weighing the total number of clusters harvested from each vine. Directly after weighing, in the laboratory, a composite sample of berries from each entry was passed through a juicer and $\approx 50 \mathrm{~mL}$ of juice was collected. Grape juice was analyzed again for percent soluble solids using the same handheld digital refractometer described previously and for $\mathrm{pH}$ using a bench top $\mathrm{pH}$ meter (Accumet AR25; Fisher Scientific, Waltham, MA).

EXPERIMENTAL DESIGN AND DATA ANALYSIS. The trial was configured as a completely randomized design with four plants of the same cultivar in a plot replicated six times for a total of 24 vines per cultivar. Descriptive statistics were performed on grape phenology E-L stages, percentage vines per entry with foliage damage after a spring frost event, and percentage vines per entry yielding marketable grapes. Remaining data were analyzed with SAS software (version 9.2; SAS Institute, Cary, NC) using PROC MIXED and LSMEANS statements because data were unbalanced due to vine mortality in some entries. Means were compared using the PDMIX612 macro formatting tool developed by Saxton (1998) and a user-specified Tukey's honestly significant difference comparison test to assign letter groupings. Red and white wine cultivars were analyzed and reported separately.

\section{Results and discussion}

Temperature MONITORING, VINE GROWTH, AND BUDBREAK. A cultivar $\times$ year interaction prevented data pooling in all categories measured $(P<0.0001)$, spotlighting the variability of northwestern New Mexico's climate. Between 1 Apr. and 31 Oct. 2010-12, the coolest growing season was in 2011 [ 1745 GDD (reported in degree celsius)], whereas the warmest was in 2012 (1976 GDD) (Table 2). Average heat unit accumulation for these three growing seasons (1840 GDD) was 61 units greater than the 44-year average for the ASCFarmington (1779 GDD) (Table 2). When comparing the ASC-Farmington's 3 -year GDD mean to other intermountain western U.S. sites, heat unit accumulation was greater than Summerland, BC, Canada [1143 GDD between 1993 and 1995 (Reynolds et al., 2004)]; Reno, NV [1277 GDD (Evans et al., 2005)]; Parma, ID [1647 GDD between 2002 and 2005 and 1487 GDD over 78 years (Shellie, 2007)]; and slightly less than Grand Junction, CO [1839 GDD between 1964 and 1990 (Hamman, 1993)].

Like other intermountain western U.S. sites, large diurnal temperature swings (around $20^{\circ} \mathrm{C}$ difference between minimum and maximum daily temperatures) were observed at the ASC-Farmington throughout the study period as illustrated for 2010 (Fig. 1). Although these warm/cool fluctuations are desirable during berry ripening, temperature extremes during fall, winter, and spring do not permit slow acclimation and deacclimation of vines into and out of winter dormancy, making tissue and buds susceptible to winterkill and spring frost damage (Dami et al., 2012; Fennell, 2004; Mills et al., 2006). Further, although frost period tapers at lower-elevation intermountain western U.S. sites, even at higher latitudes, ASC-Farmington's frost risk period extends well into May (Fig. 1). Opposing forces presented by northwestern New Mexico's high-elevation extreme diurnal temperature fluctuation and early season heat unit accumulation at northwestern New Mexico's lower latitude, work to both stimulate budbreak and cause bud mortality in the event of a spring frost event.

Historical data show average frostfree period for the ASC-Farmington is between 20 Apr. and 21 Oct. or 184 frost-free days (Table 2). Using the ASC-Farmington's 44-year historical weather data and the Frost Risk model (Snyder and de Melo-Abreu, 2006 ), data indicated a $96 \%$ probability of a spring frost $\left(\leq-2.2{ }^{\circ} \mathrm{C}\right)$ occurring on 1 Apr. $(\approx 92$ DOY) tapering to $56 \%$ on 30 Apr. $(\approx 121$ DOY), $11 \%$ on 15 May ( $\approx 136$ DOY), down to $0 \%$ by 30 May ( $\approx 151$ DOY). Indeed, vines breaking dormancy before 30 Apr. 2010 (120 DOY), 2 May 2011 (122 DOY), and 27 May 2012 (148 DOY) (Fig. 2 and Table 3 ) were damaged by frost, particularly early budding cultivars Baco Noir, Kozma 55, Leon Millot, Siegfried, Valvin Muscat, and Chardonel (Fig. 2). Average budbreak dates for red cultivars were 19 Apr. 2010 (109 DOY), 4 May 2011 (124 DOY), and 9 Apr. 2012 (100 DOY) (Table 3). Average budbreak dates for white cultivars were 21 Apr. 2010 (111 DOY), 6 May 2011 (124 DOY), and 12 Apr. 2012 (103 DOY) (Table 3 ). There was $\approx 23$ to $24 \mathrm{~d}$ between average budbreak for red and white grape cultivars, respectively, in 2011 (latest year for budbreak) when compared with 2012 (earliest year for budbreak) due to about a $12.5 \%$ difference in heat unit accumulation in 2012 when compared with 2011 (Table 2).

Harvest was completed before occurrence of fall frost, and 'Leon Millot' was one of the earliest harvested 
Table 2. Climate data during the 2010-12 growing seasons compared with the 44-year mean for New Mexico State University Agricultural Science Center at Farmington, NM [elevation $1720 \mathrm{~m}$ (5643.0 ft)]. Growing degree days, average daily maximum and minimum temperatures by mo., extreme minimum temperature, last and first spring frost dates, frost free days and dates experiencing killing spring frost events.

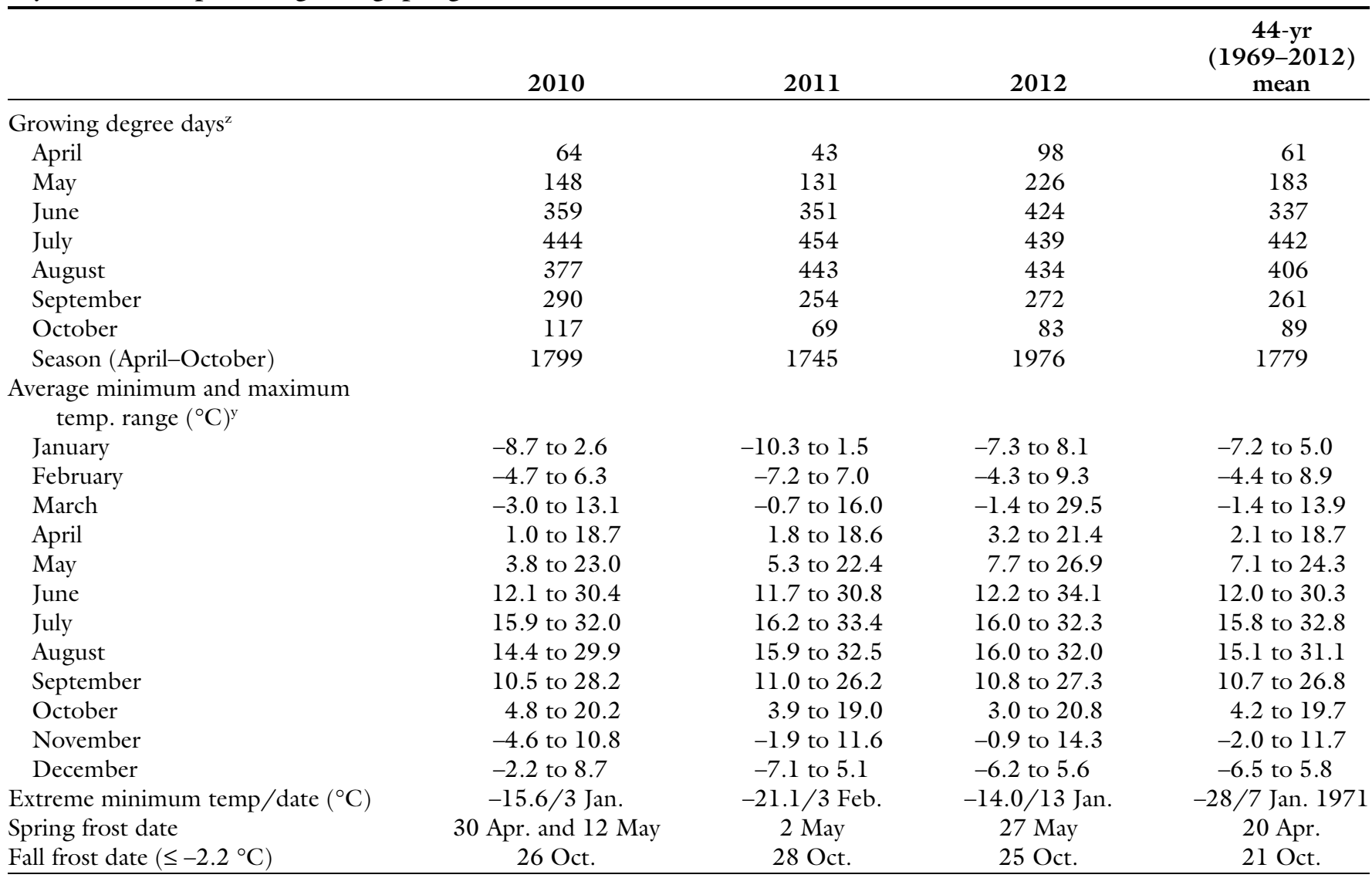

${ }^{\mathrm{z}}$ Growing degree days are calculated using a simple daily average with a base of $10{ }^{\circ} \mathrm{C}$ and no upper limit (Winkler et al., 1974$)$. We calculated GDD in ${ }^{\circ} \mathrm{C}$; $1.8 \times$ GDD $\left({ }^{\circ} \mathrm{C}\right)=$ GDD $\left({ }^{\circ} \mathrm{F}\right)$.

$\mathrm{y}\left(1.8 \times{ }^{\circ} \mathrm{C}\right)+32={ }^{\circ} \mathrm{F}$.

among red cultivars while there was less consistency among white grape cultivars (Table 3 ). Hybrids yielded consistently and on more vines when compared with European wine grape cultivars (Fig. 2 and Table 3 ) because these vines are capable of yielding a partial crop on canes derived from latent, secondary buds. For instance, among red cultivars, Baco Noir and Leon Millot managed to yield on greater than $88 \%$ of their vines, whereas among white cultivars Siegfried, Vidal Blanc, Seyval Blanc, Chardonel, Traminette, and Valvin Muscat produced on $>75 \%$ of their vines in all years studied (Fig. 2). Yielding in 2010 and 2011, 'Kozma 55' suffered $74 \%$ spring frost foliar damage in 2012 and consequently produced grapes on only $38 \%$ of its vines that year (Fig. 2 and Table 3). European wine grape cultivars faired much worse than interspecific hybrids. Among red cultivars, Malbec and Sangiovese failed to produce fruit in 2010 and 2011 (Fig. 2 and Table 3 ) and were removed from the analysis in 2012. 'Agria' yielded in 2010 but failed in 2011 and was also removed from the study in 2012. 'Pinot Noir' and 'Refosco' did not yield in 2010 but managed to produce light crops on surviving vines in 2011 and 2012 (Fig. 2 and Table $3)$. Among white cultivars, Sauvignon Blanc failed to produce fruit in 2010 and 2011 and was removed from the study in 2012, whereas Viognier and Müller-Thurgau produced only in 2012 (Fig. 2 and Table 3 ).

Four Corners region winter temperatures sometimes drop below -20 ${ }^{\circ} \mathrm{C}$ for short periods. From 2010 to 2012 , extreme winter temperatures recorded at the ASC-Farmington were $-15.6{ }^{\circ} \mathrm{C}$ on 3 Jan. 2010, $-21.1^{\circ} \mathrm{C}$ on $3 \mathrm{Feb} .2011$, and -14.0 ${ }^{\circ} \mathrm{C}$ on 13 Jan. 2012 (Table 2). The coldest winter temperatures recorded during 44 years of measurement at the station were $-28.0,-25.6$, and $-26.7^{\circ} \mathrm{C}$ in Jan. 1971, Feb. 1989, and Dec. 1990, respectively (D. Smeal, unpublished data). The years 2010 and 2012 were somewhat similar because vines presumably sustained more damage related to spring frost events than to winter kill. The year 2011 stands out because winter temperatures were colder than 2010 and 2012 and the 2011 spring was generally cooler, permitting a slower deacclimation of vines than in 2010 or 2012 . This is probably why vine damage due to spring frost was less problematic in that year than winterkill. Spring E-L measurements and frost damage assessments combined with lack of harvest data for 'Agria', 'Malbec', 'Müller-Thurgau', 'Sangiovese', and 'Sauvignon Blanc' suggest these cultivars suffered spring frost damage in 2010 and winter budkill during the 2011 winter (Fig. 2 and Table 3). Many of these vines had to 


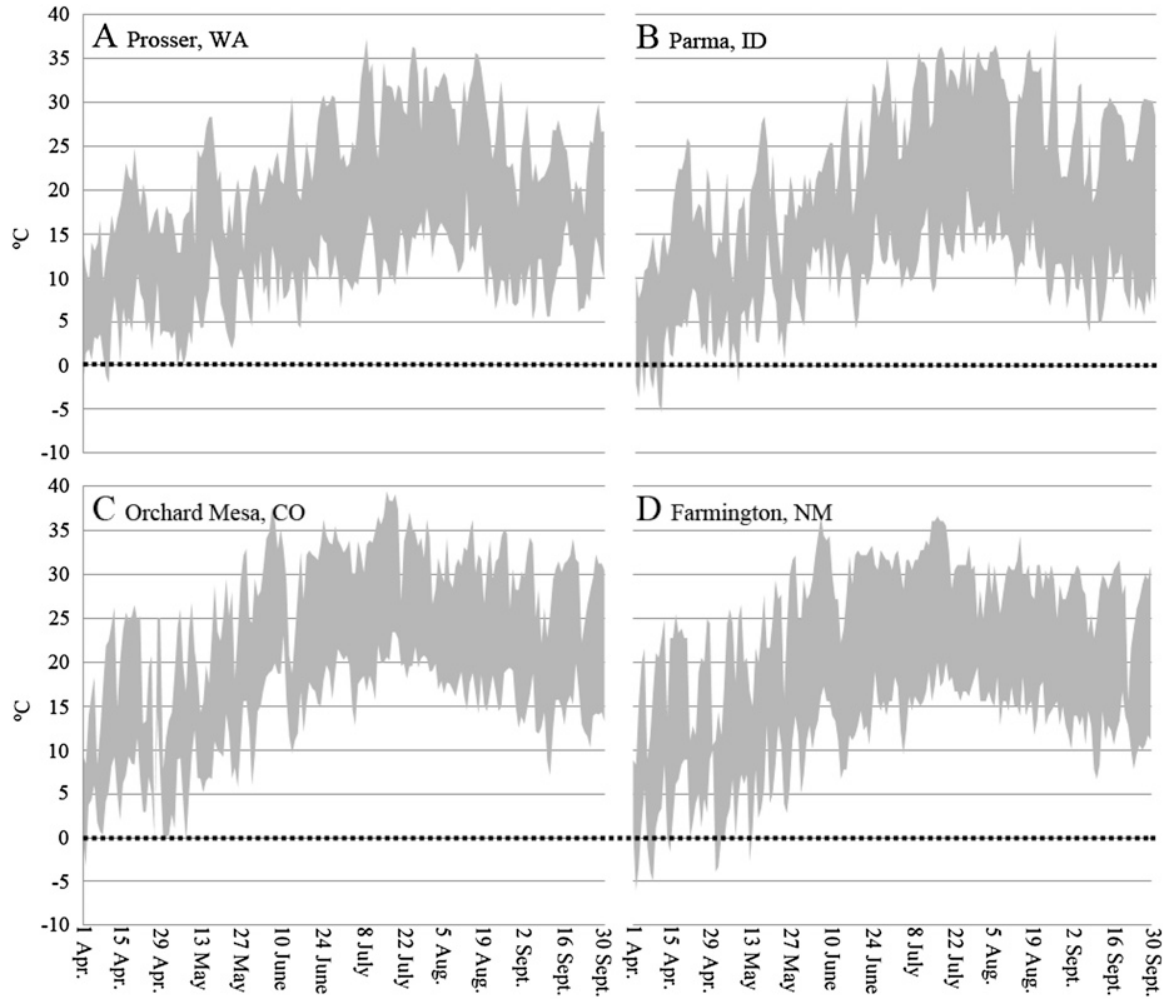

Fig. 1. 2010 minimum and maximum diurnal temperatures at four intermountain western U.S. locations indicating spring frost risk beginning 1 Apr.: (A)

Washington State University Irrigated Agricultural Experiment Station, Prosser, WA, Washington State University HQ weather station (lat. $46.3^{\circ} \mathrm{N}$, long. $119.7^{\circ} \mathrm{W}$, elevation $265 \mathrm{~m}$ ); (B) University of Idaho, Parma, ID AgriMet Weather Station (lat. $43.8^{\circ} \mathrm{N}$, long. $116.93^{\circ} \mathrm{W}$ elevation $703 \mathrm{~m}$ ); (C) Colorado State University Orchard Mesa Experiment Station CoAgMet weather station ORM01, Orchard Mesa, CO (lat. 39.04 ${ }^{\circ} \mathrm{N}$, long. $108.46^{\circ} \mathrm{W}$ elevation $1402 \mathrm{~m}$ ); (D) New Mexico State University Agricultural Science Center at Farmington, NM National Weather Service weather station (lat. $36^{\circ} 41^{\prime} 20.95^{\prime \prime} \mathrm{N}$, long. $108^{\circ} 18^{\prime} 45.56^{\prime \prime} \mathrm{W}$, elevation $1720 \mathrm{~m})$. Dashed line refers to $0{ }^{\circ} \mathrm{C} ; 1 \mathrm{~m}=3.2808 \mathrm{ft}\left(1.8 \times{ }^{\circ} \mathrm{C}\right)+32={ }^{\circ} \mathrm{F}$.

be retrained, which is why frost damage assessments especially for these European wine grape cultivars is potentially misleading. We did not control the condition of primary buds before bud swell nor after spring frost events. In retrospect, we see such information is valuable for being able to clearly differentiate between buds that were winterkilled or damaged in spring.

Budkill in grape varies by genotype (Mills et al., 2006; Rombough, 2002; Wolf and Cook, 1994). Rombough (2002) reports European wine grape vines are generally hardy to $\approx-20^{\circ} \mathrm{C}$ with some cultivars from northern Europe reported to withstand temperatures down to $-29^{\circ} \mathrm{C}$. For two European wine grape cultivars, Mills et al. (2006) reported 94\% phloem damage and 30\% xylem damage at $-18{ }^{\circ} \mathrm{C}$ in Chardonnay, and $80 \%$ phloem damage at $-20{ }^{\circ} \mathrm{C}$ and
$28 \%$ xylem damage at $-23{ }^{\circ} \mathrm{C}$ in Cabernet Sauvignon. Dami et al. (2012) reported European wine grape cultivars to be most sensitive to subfreezing temperatures, sustaining $93 \%$ bud injury at $-26^{\circ} \mathrm{C}$, whereas hybrids sustained only $12 \%$ to $35 \%$ primary bud injury. Lisek (2012) reported similar findings in a survey of 40 wine grape cultivars grown in Poland experiencing a winter low of -28.1 ${ }^{\circ} \mathrm{C}$ : cultivars Auror, Delaware, Leon Millot, Marechal Foch, Siberia, Saphira, and Seyval received rankings of very resistant or resistant to subfreezing winter temperatures. Similar findings have been reported in western Colorado (Colorado State University, 1996). Reynolds et al. (2004) noted that 'Kozma 55' had good potential in Summerland, BC, Canada, whereas Masabni and Wolfe (2007) reported moderate winter injury in the same clone planted in Kentucky.
Because European wine grape cultivars performed so poorly, no further discussion is made for these cultivars in the current report.

Harvest. As vines matured, average clusters per vine ranged from 8.7 in 2010 to 36.6 in 2012 among red cultivars and 21.1 (2010) to 30.7 (2012) among white cultivars (Table $4)$. Mean total yield per vine ranged from $0.5 \mathrm{~kg} /$ vine (2010) to $1.3 \mathrm{~kg} /$ vine (2012) for red cultivars, and $1.9 \mathrm{~kg} /$ vine (2010) to $1.0 \mathrm{~kg} /$ vine $(2012)$ for white cultivars (Table 4). 'Vidal Blanc' and 'Seyval Blanc' produced fewer clusters and had lower yield weights in 2012 than the previous year possibly due to low $\mathrm{N}$ inputs in 2012 in combination with clusters formed from secondary buds. Reynolds et al. (2004) reported declining yield differences in their experimental vineyard treated under certified organic conditions mainly due to low $\mathrm{N}$ inputs.

Target soluble solids content was reached in most entries in 2010 and 2011 and to a lesser extent in 2012 (Table 5). Because 2012 sustained above-average temperatures in May and June (Table 2), many cultivars were harvested early in 2012 to prevent widespread sunscald damage. For top-performing red cultivars, percent soluble solids by year (2010, 2011 , and 2012, respectively) follows: Baco Noir $(28.0 \%, 23.4 \%$, and $21.8 \%)$, Kozma 55 (26.3\%, 21.6\%, and $22.9 \%$ ), and Leon Millot $22.6 \%$, $22.8 \%$, and $18.1 \%$ ) (Table 5). Percent soluble solids (3-year mean) for white cultivars ranged from $19.9 \%$ (Vidal Blanc) to $24.6 \%$ (Chardonel), and 'Chardonel' consistently had the highest sugar content (Table 5). Most cultivars fell within acceptable ranges for juice $\mathrm{pH}$ (between 3.0 and 3.8) as reviewed by Kodur (2011). Red cultivar juice $\mathrm{pH}$ ranged from 3.3 to 3.4 in $2010,3.1$ to 3.5 in 2011 , and 2.9 to 3.2 in 2012 . For white cultivars, Traminette had the lowest $\mathrm{pH}$ in all 3 years (2.9-3.0) compared with Valvin Muscat (pH 3.4-3.5).

Cultivar recommendations alone are insufficient to avoid risk of crop and/or vine losses due to freeze injury, especially at high elevations like northwestern New Mexico. Excellent resources pertaining to preventing or managing freeze damage risk in vineyards have been published and should also guide growers who have already 

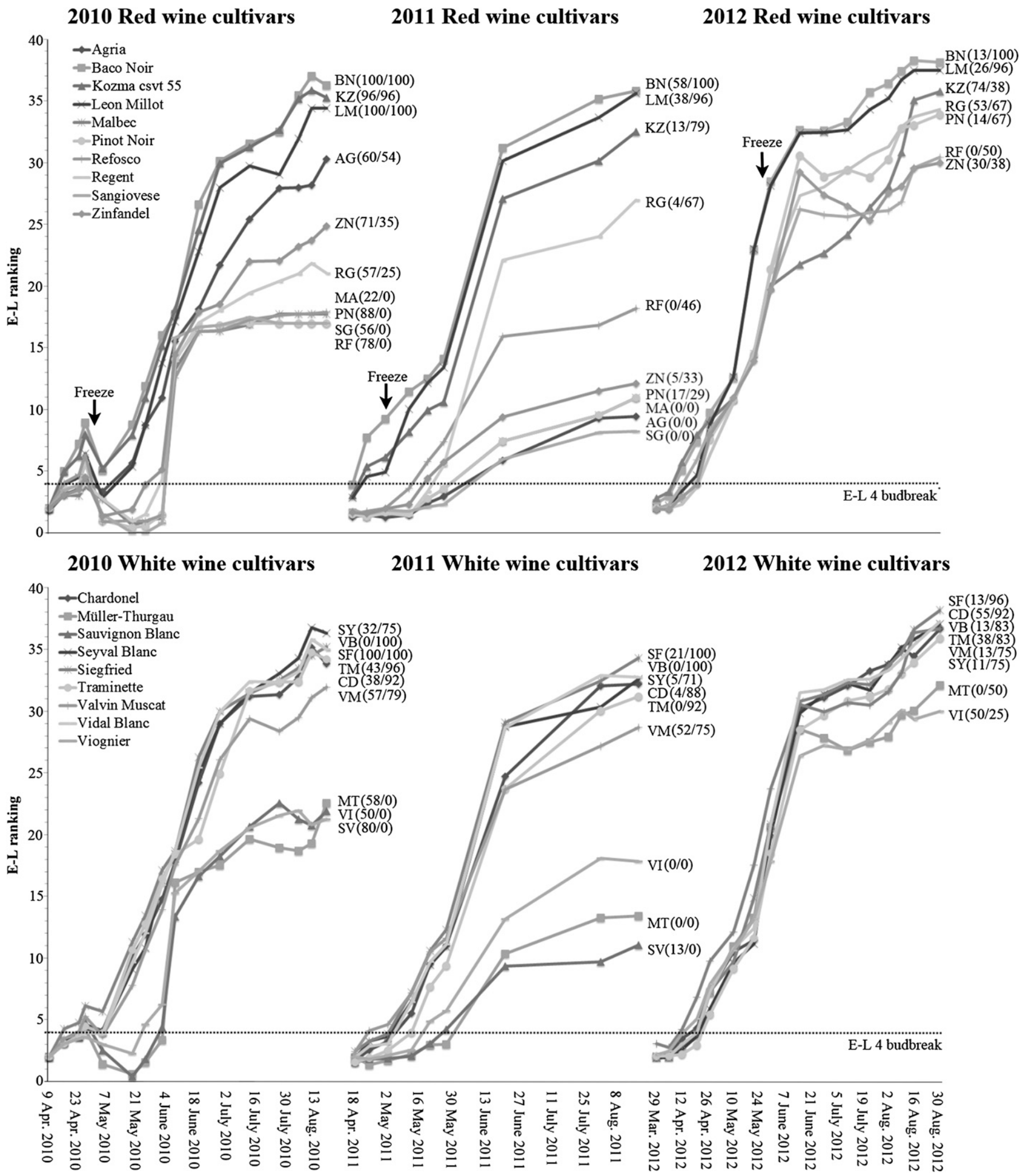

Fig. 2. Descriptive statistics for modified Eichorn and Lorenz [E-L (Coombe, 1995)] evaluations for 19 red and white European and interspecific hybrid wine grape cultivars evaluated 2010-12 at the New Mexico State University Agricultural Science Center at Farmington, NM [elevation $1720 \mathrm{~m}(5643.0 \mathrm{ft})$ ] with percentage vines recording foliar frost damage and percentage vines yielding in parenthesis. Excluding harvest date, modified E-L measurements were performed on 16 dates in 2010,9 dates in 2011, and 16 dates in 2012. Refer to Table 1 for cultivar abbreviations. Modified E-L 4 (dashed line) indicates budbreak. Percentage frost damage (first number in parentheses) indicates the number of vines out of total vines in a cultivar entry recording foliar damage when measured after 30 Apr. and 12 May 2010, 2 May 2011, and 27 May 2012 frost events. Percentage vines yielding (second number in parentheses) indicates the percentage number of vines out of total vines in a cultivar entry recording grape clusters at harvest. 
Table 3. Budbreak and harvest for 19 red and white European and interspecific hybrid wine grape cultivars evaluated 201012 at the New Mexico State University Agricultural Science Center at Farmington, NM [elevation $1720 \mathrm{~m}(5643.0 \mathrm{ft})$ ]. Cultivars within berry color are listed in order of average (2010-12) budbreak day of year.

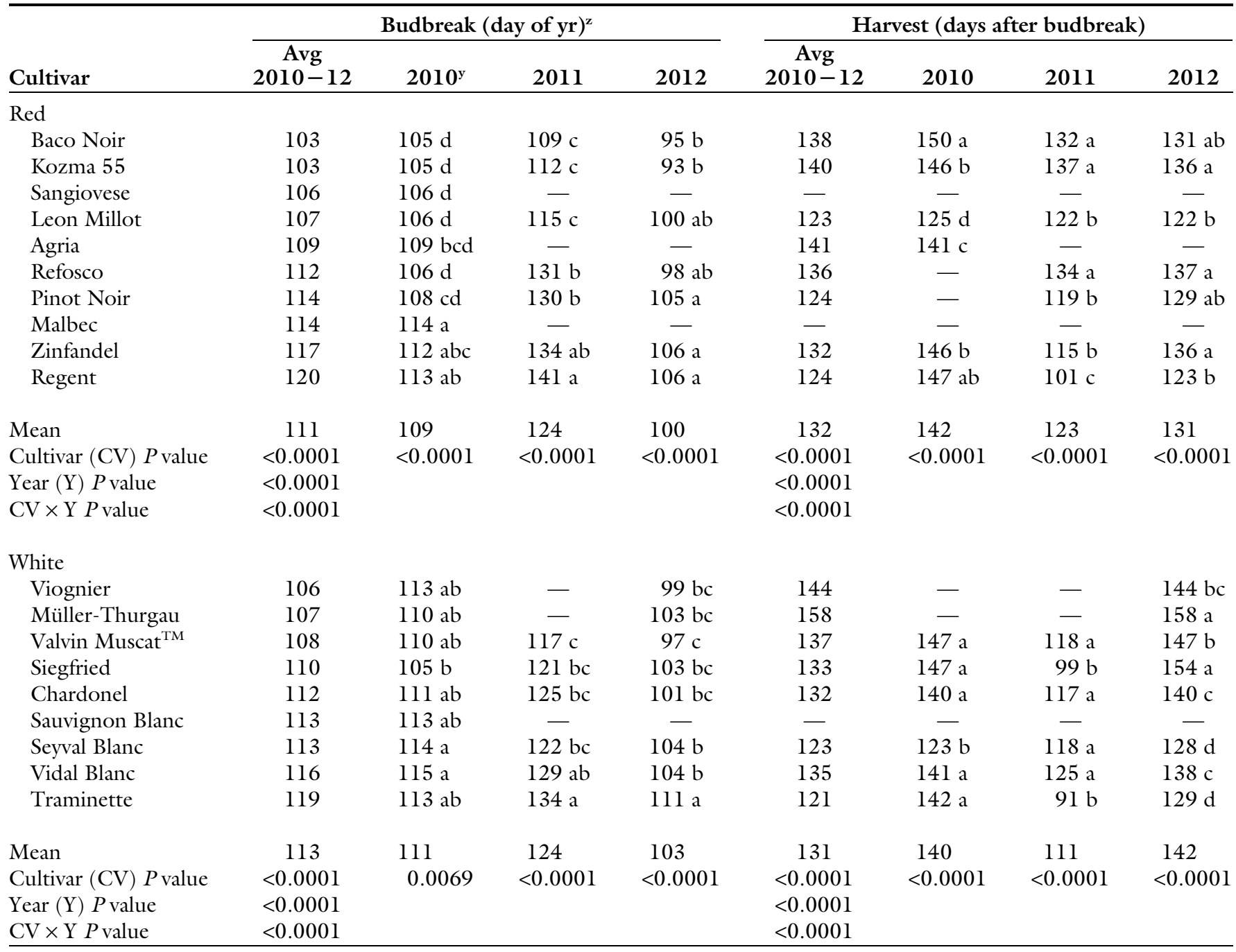

${ }^{2}$ Conversion from day of year to calendar date is based on National Aeronautics and Space Administration (2013).

${ }^{y}$ Means within a column followed by the same letter are not significantly different according to Tukey's honestly significant difference (HSD) pairwise comparison test at $P \leq 0.05$.

planted grape vines or who are considering a vineyard. Strategies to mitigate risk associated with winter kill and spring frost include late season irrigation to replenish the root zone after harvest (Davenport et al., 2008; Moyer et al., 2011), training multiple canes from the ground to increase survival potential (Howell, 2003), and late season pruning leaving more buds which are then removed after the last danger of frost (Dami et al., 2012; Howell, 2003). Other strategies include burying canes during winter for bud and cane protection (Kaiser et al., 2008), air mixing using fans and/or overhead sprinklers when temperatures hover at $0{ }^{\circ} \mathrm{C}$ (Davenport et al., 2008; Snyder et al., 2005), and use of topical foliar sprays before a spring frost event (Francko et al., 2011). Each of these strategies carries an associated cost in terms of time and money invested, and may be cost prohibitive to small-scale producers. On the other hand, choosing upland sites with good air drainage is the single most important and least expensive method of frost protection (Davenport et al., 2008; Hamman et al., 1998; Howell, 2003; Moyer et al., 2011; Snyder et al., 2005). Even so, we experienced spring frost damage and winter kill between 2010 and 2012 at an upland site. Northwestern New Mexico growers in irrigated valleys, where frost damage and colder winter temperatures are even more likely to occur because of the presence of frost pockets (Moyer et al., 2011), are cautioned to choose sites very carefully before selecting cultivars.

\section{Conclusion}

This work was conducted at an intermountain western U.S. site above $1700 \mathrm{~m}$. Interspecific hybrids outperformed European wine grape cultivars in establishment and yield. Weather data show northwestern New Mexico begins accumulating heat units in early spring yet late spring freeze events like ones we observed in May in all three measurement years pose a high crop loss risk. Site selection to avoid frost pockets is of utmost importance (along with soil testing for $\mathrm{pH}$, salinity and nutrient content). Every high-elevation grower 
Table 4. Yield characteristics of top performing red and white interspecific hybrid wine grape cultivars evaluated 2010-12 at the New Mexico State University Agricultural Science Center at Farmington, NM [elevation $1720 \mathrm{~m}$ (5643.0 ft)]. Cultivars within berry color are listed in order of average clusters/vine in 2010-12.

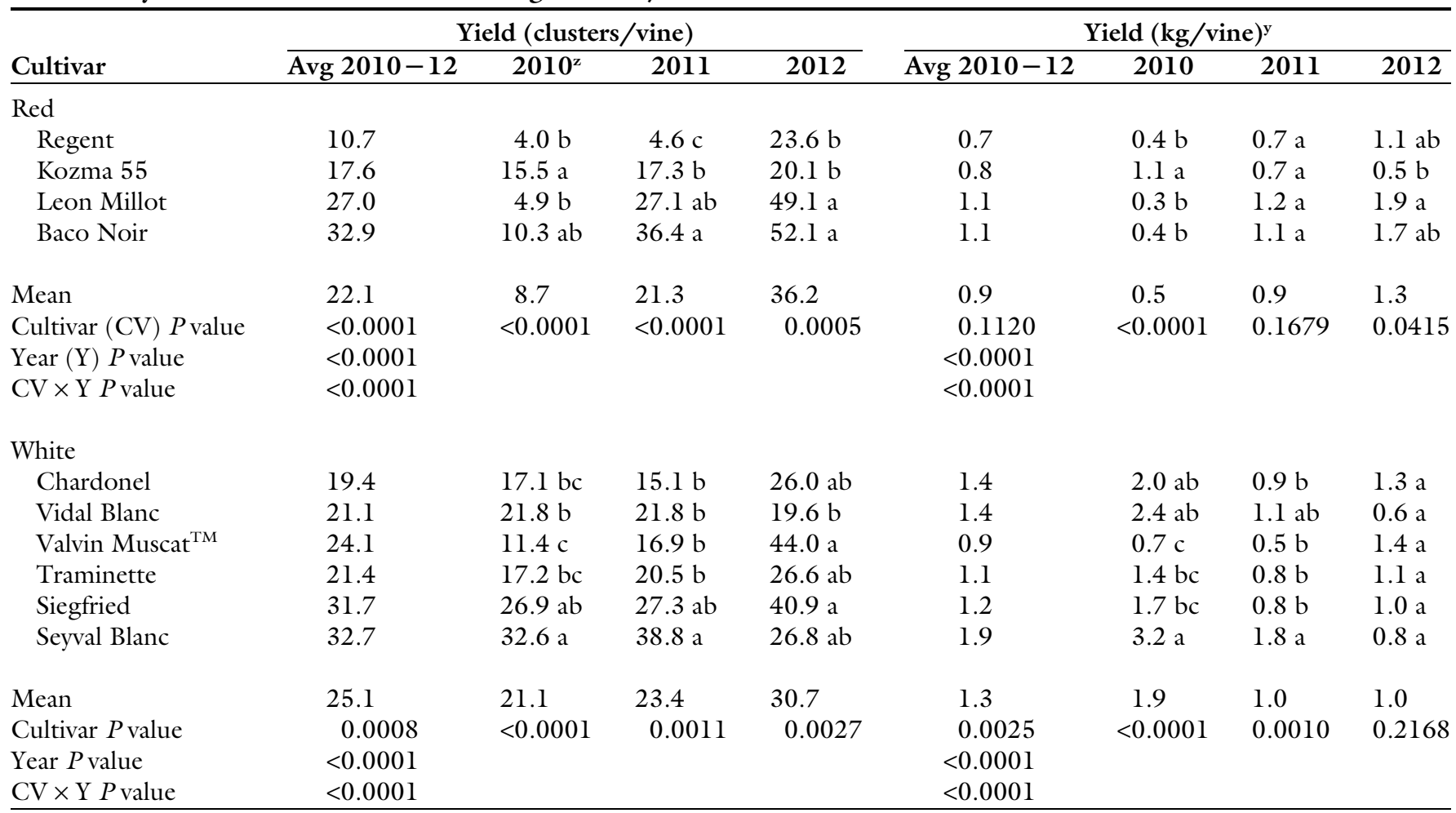

${ }^{\mathrm{z}}$ Means within a column followed by the same letter are not significantly different according to Tukey's honestly significant difference (HSD) pairwise comparison test at $P \leq 0.05$. ${ }^{\mathrm{y}} \mathrm{l} \mathrm{kg}=2.2046 \mathrm{lb}$.

Table 5. Juice composition of top performing red and white wine interspecific hybrid grape cultivars evaluated 2010-12 at the New Mexico State University Agricultural Science Center at Farmington [elevation $1720 \mathrm{~m}(5643.0 \mathrm{ft})$ ]. Cultivars within berry color are listed in order of average juice percent soluble solids in 2010-12.

\begin{tabular}{|c|c|c|c|c|c|c|c|c|}
\hline \multirow[b]{2}{*}{ Cultivar } & \multicolumn{4}{|c|}{ Juice soluble solids (\%) } & \multicolumn{4}{|c|}{ Juice $\mathrm{pH}$} \\
\hline & Avg 2010-12 & $2010^{z}$ & 2011 & 2012 & Avg 2010-12 & 2010 & 2011 & 2012 \\
\hline \multicolumn{9}{|l|}{ Red } \\
\hline Leon Millot & 21.2 & $22.6 \mathrm{c}$ & $22.8 \mathrm{a}$ & $18.1 \mathrm{bc}$ & 3.3 & $3.3 \mathrm{~b}$ & $3.5 \mathrm{a}$ & $3.1 \mathrm{ab}$ \\
\hline Kozma 55 & 23.6 & $26.3 \mathrm{~b}$ & $21.6 \mathrm{ab}$ & $22.9 \mathrm{a}$ & 3.2 & $3.3 \mathrm{~b}$ & $3.1 \mathrm{~b}$ & $3.1 \mathrm{ab}$ \\
\hline Baco Noir & 24.4 & $28.0 \mathrm{a}$ & $23.4 \mathrm{a}$ & $21.8 \mathrm{ab}$ & 3.1 & $3.3 \mathrm{~b}$ & $3.1 \mathrm{~b}$ & $2.9 \mathrm{~b}$ \\
\hline Cultivar $(\mathrm{CV}) P$ value & $<0.0001$ & $<0.0001$ & 0.0016 & 0.0028 & 0.0400 & 0.0038 & $<0.0001$ & 0.0028 \\
\hline Year $(\mathrm{Y}) P$ value & $<0.0001$ & & & & $<0.0001$ & & & \\
\hline $\mathrm{CV} \times \mathrm{Y} \mathrm{P}$ value & $<0.0001$ & & & & $<0.0001$ & & & \\
\hline \multicolumn{9}{|l|}{ White } \\
\hline Traminette & 21.6 & $24.9 \mathrm{ab}$ & $19.8 \mathrm{~b}$ & $20.2 \mathrm{abc}$ & 2.9 & $3.0 \mathrm{~b}$ & $2.9 \mathrm{c}$ & $2.9 \mathrm{~d}$ \\
\hline Chardonel & 24.6 & $27.5 \mathrm{a}$ & $22.3 \mathrm{a}$ & $23.9 \mathrm{a}$ & 3.1 & $3.1 \mathrm{ab}$ & $3.1 \mathrm{bc}$ & $3.0 \mathrm{~cd}$ \\
\hline Mean & 21.5 & 23.1 & 20.4 & 21.1 & 3.2 & 3.2 & 3.1 & 3.2 \\
\hline Cultivar (CV) $P$ value & $<0.0001$ & $<0.0001$ & 0.0035 & 0.0020 & $<0.0001$ & 0.0008 & $<0.0001$ & $<0.0001$ \\
\hline Year (Y) Pvalue & $<0.0001$ & & & & 0.0011 & & & \\
\hline $\mathrm{CV} \times \mathrm{Y} \mathrm{P}$ value & $<0.0001$ & & & & $<0.0001$ & & & \\
\hline
\end{tabular}

${ }^{\mathrm{z}}$ Means within a column followed by the same letter are not significantly different according to Tukey's honestly significant difference (HSD) pairwise comparison test at $P \leq 0.05$. 
should evaluate their risks and markets carefully in relation to climate, soil, and what they can afford before planting any crop, including wine grape. Should decisions to pursue grape production be made, then Four Corner regional growers are encouraged to select cultivars capable of sustaining periodic winter temperatures below $-20{ }^{\circ} \mathrm{C}$ yielding on canes originating from latent, secondary buds after a spring frost event. In this study, these cultivars were interspecific hybrids. These data form the basis of ongoing testing and future reports to inform agricultural producers in the Four Corners region and similar highelevation intermountain western U.S. sites. Evaluating winter bud status will permit a clearer understanding of bud survival activity. Evaluating titratable acidity and wine sensory attributes will permit greater inferences on grape juice quality.

\section{Literature cited}

Caspari, H. and A. Montano. 2012. Budbreak and harvest dates for 31 grape varieties growing at the Western Colorado Research Center near Grand Junction, CO. 12 Nov. 2012. <http://www.colostate. edu/programs/wcrc/pubs/viticulture/ vbbandhgraphs1.pdf $>$.

Colorado State University. 1996. Grape varieties for cold areas of Colorado. 12 Nov. 2012. <http://www.coopext. colostate.edu/TRA/PLANTS/gpvar. shtml>.

Coombe, B.G. 1995. Adoption of a system for identifying grapevine growth stages. Austral. J. Grape Wine 1:104-110.

Dami, I.E., S. Ennahli, and Y. Zhang. 2012. Assessment of winter injury in grape cultivars and pruning strategies following a freeze stress event. Amer. J. Enol. Viticult. 63:106-111.

Davenport, J.R., M. Keller, and L.J. Mills. 2008. How cold can you go? Frost and winter protection for grape. HortScience 43:1966-1969.

Dutt, G.R., E.A. Mielke, and W.H. Wolfe. 1981. The use of soils for the delineation of viticultural zones in the Four Corners region. Amer. J. Enol. Viticult. 32:290-296.

Evans, J., E.A.R. Tattersall, W. Johnson, and G.R. Cramer. 2005. Towards wine grape (Vitis vinifera) vineyard establishment in northern Nevada. Univ. Nevada Agr. Expt. Sta. Publ.1055382. 12 Nov. 2012. <http://www.ag.unr.edu/cramer/ publications/viniferafactsheet.pdfs.
Fallahi, E., B. Fallahi, B. Shafii, and J.C. Stark. 2005. Performance of six wine grapes under southwest Idaho environmental conditions. Small Fruits Rev. 4:77-84.

Fennell, A. 2004. Freezing tolerance and injury in grapevines. J. Crop Improv. 10:201-235.

Francko, D.A., K.G. Wilson, Q.Q. Li, and M.A. Equiza. 2011. A topical spray to enhance plant resistance to cold injury and mortality. HortTechnology 21:109-118.

Hamman, R.A. 1993. Wine grape performance of 32 cultivars in western Colorado 1982-1986. Fruit Var. J. 47:59-63.

Hamman, R.A., S.D. Savage, and H.J. Larsen. 1998. The Colorado grape growers' guide. Colorado Agr. Expt. Sta. Bul. 550A. 12 Nov. 2012. <http:// www.ext.colostate.edu/pubs/garden/ 550a.pdf $>$.

Howell, S. 2003. Factors related to spring frost damage: What are the options. 3 Mar. 2013. <http://www.grapes.msu. edu/pdf/cultural/factors-related.pdf>.

Kaiser, C., P. Skinkis, and M. Olmstead. 2008. Protecting grapevines from winter injury. Pacific Northwest Ext. Publ. PNW 603-E. 5 Nov. 2012. <http://extension. oregonstate.edu/catalog/pdf/pnw/ pnw603-e.pdfs.

Keetch, C.W. 1980. Soil survey of San Juan County New Mexico: Eastern part. U.S. Dept. Agr., Washington, DC.

Keller, M., L.J. Mills, R.L. Wample, and S.E. Spayd. 2005. Cluster thinning effects on three deficit-irrigated Vitis vinifera cultivars. Amer. J. Enol. Viticult. 56:91103.

Kodur, S. 2011. Effects of juice $\mathrm{pH}$ and potassium on juice and wine quality, and regulation of potassium in grapevines through rootstocks (Vitis): A short review. Vitis 50:1-6.

Lisek, J. 2012. Winter frost injury of buds on one-year-old grapevine shoots of Vitis vinifera cultivars and interspecific hybrids in Poland. Folia Horticulturae 24:97103.

Masabni, J. and D. Wolfe. 2007. Eastern European grape cultivars. Univ. Kentucky Coop. Ext. Serv. HortFact-3007.

McMaster, G.S. 1997. Growing degreedays: One equation, two interpretations. Agr. For. Meteorol. 87:291-300.

Mielke, E.A., G.R. Dutt, S.K. Hughes, W.H. Wolfe, G.J. Loeffler, R. Gomez, M.D. Bryant, J. Watson, and S.H. Schick. 1980. Grape and wine production in the Four Corners region. Univ. Arizona Agr. Expt. Sta. Rpt. 239.
Mills, L.J., J.C. Ferguson, and M. Keller. 2006. Cold-hardiness evaluation of grapevine buds and cane tissues. Amer. J. Enol. Viticult. 57:194-200.

Minder, J.R., P.W. Mote, and J.D. Lundquist. 2010. Surface temperature lapse rates over complex terrain: Lessons from the Cascade Mountains. J. Geophys. Res. 115:1-13.

Moyer, M., L. Mills, G. Hoheisel, and M. Keller. 2011. Assessing and managing cold damage in Washington vineyards. Washington State Univ. Ext. Bul. EM042E.

National Aeronautics and Space Administration. 2013. Julian date calendar/calculator for converting Julian date to day of year. 12 Feb. 2013. <http://www-air. larc.nasa.gov/tools/jday.htm>.

New Mexico Climate Center. 2013. New Mexico State Univ. Farmington-ASC weather station. 18 Apr. 2013. <http:// weather.nmsu.edu>.

Reisch, B.I., R.M. Pool, W.B. Robinson, T. Henick-Kling, B.K. Gavitt, J.P. Watson, M.H. Martens, R.S. Luce, and H.C. Barrett. 1996. 'Traminette' grape. New York Food Life Sci. Bul. 149. 6 Mar. 2013. <http://www. hort.cornell.edu/reisch/grapegenetics/ Traminette.pdf>.

Reisch, B.I., R.M. Pool, W.B. Robinson, T. Henick-Kling, J.P. Watson, K.H. Kimball, M.H. Martens, G.S. Howell, D.P. Miller, C.E. Edson, and J.R. Morris. 1990. 'Chardonel'. New York Food Life Sci. Bul. 132. 6 Mar. 2013. <http://www. hort.cornell.edu/reisch/grapegenetics/ bulletin/chardonel.html .

Reisch, B.I., R.S. Luce, B. Bordelon, and T. Henick-Kling. 2006. 'Valvin Muscat' grape. New York Food Life Sci. Bul. 161. 6 Mar. 2013. <http://fls.cals.cornell. edu/OCRPDF/fls161.pdf>.

Reynolds, A.G., M. Cliff, D.A. Wardle, and M. King. 2004. Evaluation of winegrapes in British Columbia: New cultivars and selections from Germany and Hungary. HortTechnology 14:420-436.

Rolland, C. 2002. Spatial and seasonal variations of air temperature lapse rates in alpine regions. J. Clim. 16:1032-1046.

Rombough, L. 2002. The grape grower: A guide to organic viticulture. Chelsea Green Publishing, White River Junction, VT.

Saxton, A.M. 1998. A macro for converting mean separation output to letter groupings in PROC MIXED. 10 Jan. 2012. <http://www2.sas.com/proceedings/ sugi23/Stats/p230.pdfs.

Shellie, K.C. 2007. Viticultural performance of red and white wine grape cultivars 
in southwestern Idaho. HortTechnology 17:595-603.

Smeal, D., M.K. O’Neill, C.K. Owen, Z.F. Williams, M.M. West, and R.N. Arnold. 2006. Thirty five years (19692003) of climatological data: NMSU's Agricultural Science Center at Farmington, New Mexico. New Mexico State Univ. Agr. Expt. Sta. Res. Rpt. 756.

Snyder, R.L. and J.P. de Melo-Abreu. 2006. FriskNH p. An Excel application to estimate probabilities for the last freeze in the spring. 7 Dec. 2012.<http://biomet. ucdavis.edu/frost-protection.html $>$.

Snyder, R.L., J.P.d. Melo-Abreu, and S. Matulich. 2005. Frost protection: Fundamentals, practice, and economics. United Nations Food Agr. Organization Press, Rome, Italy.

Vitis International Variety Catalogue. 2007. Vitis International Variety Catalogue. 17 May 2013. <http://www. vivc.de $>$.
Wallace, J.M. and P.V. Hobbs. 2006. Atmospheric Science. 2nd ed. Academic Press. Burlington, MA.

Winkler, A.J., J.A. Cook, W.M. Kliewer, and L.A. Lider. 1974. General viticulture. 2nd ed. University of California Press, Berkeley, CA.

Wolf, T.K. and M.K. Cook. 1994. Cold hardiness of dormant buds of grape cultivars: Comparison of thermal analysis and field survival. HortScience 29:14531455 . 